\title{
Comparison of Different Models in Estimating Standard Evapotranspiration in Lampung Province, Indonesia
}

\author{
Tumiar K Manik ${ }^{1}$, Purba Sanjaya ${ }^{2}$, R.A. Bustomi Rosadi ${ }^{3}$ \\ ${ }^{1,2}$ Department of Agrotechnology, Faculty of Agriculture, Lampung University, Indonesia \\ ${ }^{3}$ Department of Agriculture Engineering, Faculty of Agriculture, Lampung University, Indonesia
}

\begin{abstract}
Evapotranspiration (ET) is the loss of water to the atmosphere by combined processes of evaporation from soil and plant surfaces and transpiration from plants. Since various factors affect ET, including weather, crops and soil parameters; numerous equations have been developed to quantify standard ET. The equations vary in data requirements from very simple, empirically based or simplified equations to complex, more physically based equations. This study used six methods in estimating standard evapotranspiration using data from September 2011-August 2012 from Climate Station at Masgar $\left(05^{\circ} 10^{\prime} 20^{\prime \prime} \mathrm{S}, 105^{\circ} 10^{\prime} 49^{\prime \prime} \mathrm{E}, 50 \mathrm{~m}\right.$ dpl) Lampung, Indonesia. The six models are: HargreavesSamani 1985 (H/S), FAO 24 Radiation (24RD), FAO 24 Blaney-Criddle $(24 B C), \quad F A O \quad 24$ Pan Evaporation (24PAN), Linacre (Lina), and Makkink (Makk). The results were analyzed using statistics methods in error indicators, which are: Root Mean Square Error(RMSE), Mean Absolute Error (MAE), and Logaritmic Root Mean Square Error(LOG RMSE), while the closeness among the models was analyzed using Index Agreement (IA). Direct measurement had been done using lysimeters (3x2x1) $m$. The study concluded that Makkink model is the suitable simple model that should be chosen in Lampung lowland area to calculate $E T_{o}$ when climate data is limited, besides the recommended FAO 56 Penman Monteith.
\end{abstract}

Keyword- Evapotranspiration, Standard Evapotranspiration, FAO 56 PM, Makkink Model.

\section{INTRODUCTION}

Evaporation is the main component in hydrology cicle, therefore, accurate estimation of evaporation rate is important for water management and eventually for agriculture production. However, it is difficult to measure evaporation rate directly since evaporation affected by various factors.

Evaporation is affected by climate factors such as solar radiation, air temperature and humidity and wind velocity; by crops type and environment and by soil condition and management (Temesken, Davidov and Frame, 2005). Since those factors are linked to each other and change in time and space, it is difficult to develop equation for estimating evaporation rate for various crops on different condition. Therefore, a scheme called reference evapotranspiration was developed.

Reference ET is defined as "the rate of evapotranspiration from an extensive area of $0.08-0.15$ $\mathrm{m}$ high, uniform, actively growing, green grass that completely shades the soil and is provided with unlimited water and nutrients" (Bakhtiari et al., 2011). More recently, Allen et al. (1998) elaborated on the concept of $\mathrm{ET}_{\mathrm{o}}$, referring to an ideal $0.12 \mathrm{~m}$ high crop with a fixed surface resistance of $70 \mathrm{~s} \mathrm{~m}^{-1}$ and an albedo of 0.23 . Several equations has been developed to estimate the reference evapotranspiration; some of that were derived based on physical processes of the evapotranspiration but mostly are empirical based on ststistical relationship between evapotranspiration and one or more climate variables (Berengena and Gavilan, 2005). Approaching methods to estimate evapotranspiration rate was developed increasingly in the last 30 years such as based on air temperature measurement (Hargraeves and Sumani, 1985), based on solar radiation Priestly and Taylor method (Priestly and Taylor, 1972) and based on combination of radiation balance and air moisture aerodynamic movement (Penman, 1948).

Penman method has been improved several times such as Penmann method modified by Monteith and known as Penman-Monteith equation (Monteith, 1965) approach method in FAO 24 version (Doorenbos and Pruitt, 1977), FAO 56 modification (Allen, 1998) and recently MattShuttleworth approaching method (2009).Those estimations

have been derived and/or calibrated from the direct field measurement of ET using various grasses of alfalfas on a variety of lysimeter designs, climates, and management conditions.

Some studies showed that Penmann-Monteith model gave accurate estimation that FAO and other organizations 
recommended this model to estimate reference evapotranspiration for calculating crops water requirement (Itenfisul.et.al., 2003; Berengena dan Gavilan, 2005). Even though Penman-Monteith model is accepted as accurate estimation, for using in local condition, it is necessary to validate the model to whether it estimates close enough to the direct measurement on the local climate station. Berengena dan Gavilan (2005) examined different methods in estimating evapotranspiration rate in Southern Spain, an area with strong advection. The result showed that Penman method modified with local wind function gave the best estimation compared with direct measurement in lysimeter following with Penman-Monteith FAO 56 version. Steduto et al. (2003) examine FAO 56 method in Southern Italia with Mediteranian semi-arid climate. The results showed that FAO 56 method was the best in estimating the evapotranspiration; however, tended to be over estimated in winter time when the evapotrasnpiration was low and under estimated in summer time when the evapotraspiration was high. Temesgen et al. (2005) also examined FAO 56 in California, USA and the result showed good correlations with evapotranspiration rate in 37 climate stations in this area.

Direct measurement of evapotranspiration is calculated using lysimeters; however, only small number of climate stations is equiped with a lysimeter; as an alternative, the measurement is done using evaporation pan known as Class A pan. A study by Fontenot (2004) showed that reference evapotranspiration measurement by Class A pan was not fit to the estimation by Penman-Monteith. The result from Class $\mathrm{A}$ pan should be corrected by a coefficient. Using Cuenca and Snyder method; Xing et al.(2008) obtained that pan coefficient for Canada maritim climate was between $0.78-0.94$. Generally the result from Pan A was lower than the estimation result from Penman-Monteith or Priestley-Taylor method.

Research about comparing different models has been done in some countries. Chen et al. (2005) used 7 estimating models in four provinces of Taiwan and found that Makkink and Hargreaves-Samani models were the best models in estimating $\mathrm{ET}_{\mathrm{o}}$ when compared to FAO 56 PM. Chowhury et al. (2010) also found that in India, Makkink model had the closest estimation to FAO 56 PM with a little underestimated result.

$\mathrm{Xu}$ and Chen (2005) did similar study in Germany with comparing 7 models and found that Granger-Gray and Makkink models were the best models for the area. In North China, Scneider et al. (2007) compared 4 models with direct observation and concluded that HargreavesSamani and Makkink models were the best models in estimating $\mathrm{ET}_{\mathrm{o}}$ even better than FAO 56 PM. Jacobs et al.
(2004) conducted research on estimating $\mathrm{ET}_{\mathrm{o}}$ in Florida, using remote sensing method with data from GOES. The results showed that FAO $56 \mathrm{PM}$ is the best model with $\mathrm{R}^{2}=0.92$; however, this result was not much different with estimated results from Makkink model which gave $\mathrm{R}^{2}=0.90$.

Various methods in estimating evapotranspiration also has been applied in Indonesia. Usman (2004) compared Thornthwaite, Blaney-Cridle, Samani-Hargreaves, Prestley-Taylor, Jansen-Haise, Penman and PenmanMonteith methods in five climate stations in West Java; the results showed that in general Priestley-Taylor in average gave the highest annual evapotranspiration rate, while the lowest was obtained by Blaney-Criddle method. It also showed that estimation using Penman Monteith method in general gave higher rate than Pan A measurement.

Lampung Province $\left(103^{\circ} 40^{\prime}-105^{\circ} 50^{\prime} \mathrm{E}\right.$; and between: $6^{0} 45^{\prime}-3^{0} 45^{\prime} \mathrm{S} ; 35.288,35 \mathrm{~km}^{2}$ ) is located at Southeast tip of Sumatra Island, Indonesia. Lampung climate is characterized by monsoonal rain distribution and local characteristics. Rain season in general is from October to March with the peak on January/February and dry season is from April to September. Monthly rainfall ranges from $50-200 \mathrm{~mm}$ and annual rainfall ranges from $1200 \mathrm{~mm}$ (lowland area) to $2500 \mathrm{~mm}$ (highland area). Lampung economic is dominated by agriculture products mainly coffee, chocolate, rubber and sugarcane. Lampung is also considered as main area for cash crops such as paddy, soybean and Maize. Therefore, finding good and reliable method in estimating crops water requirement is necessary for better agriculture management.

The objective of this research was to find a closest model to the FAO 56 PM model by comparing six different models in estimating standard evapotranspiration in Lampung area, Indonesia.

\section{METHODS}

This study used six methods in evaluating potential evapotranspiration using data from September 2011 to Agustus 2012 from Climate Station at Masgar (05¹0'20" $\mathrm{S}, 105^{\circ} 10^{\prime} 49^{\prime} \mathrm{E}, 50 \mathrm{~m} \mathrm{dpl}$ ) in Lampung, Indonesia.

The six models are: Hargreaves-Samani 1985 (H/S), FAO 24 Radiation (24RD), FAO 24 Blaney-Criddle (24BC), FAO 24 Pan Evaporation (24PAN), Linacre (Lina), dan Makkink (Makk). The results from those models were compared to FAO Penman-Monteith (56PM) as the standard model.

To evaluate the relation between models, the results were analyzed using statistics methods in error indicators, which are: Root Mean Square Error (RMSE), Mean Absolute Error (MAE), dan LogaritmicRoot Mean Square 
Error (LOG RMSE), while the closeness among the models was analyzed using Index Agreement (IA).

Finally, the results were compared to the direct measurement using 3 lysimeters $(3 \times 2 \times 1 \mathrm{~m})$ planted with Sporobulus diander grass.

\subsection{Description of Models}

2.1.1 Hargreaves-Samani 1985 (H/S) (Hargreaves and Samani, 1985)

The equation of this model is:

$E T_{o}=0.0023\left(T_{\text {mean }}+17.8\right)\left(T_{\max }-T_{\min }\right)^{0.5} R_{a}$

with $\mathrm{ET}_{\mathrm{o}}$ is standard evapotranspiration ( $\mathrm{mm} /$ day), $T_{\text {mean }}$ is daily mean temperature $\left({ }^{\circ} \mathrm{C}\right), T_{\max }$ is maximum temperature $\left({ }^{\circ} \mathrm{C}\right), T_{\text {min }}$ is minimum temperature, dan $R_{a}$ is radiation on top of the atmosfer $\left(\mathrm{MJ} / \mathrm{m}^{2} /\right.$ day $)$.

2.1.2 FAO 24 Radiation (24RD) (Doorenbos and Pruitt, 1977)

The equation of this model is:

$$
E T_{o}=a+b\left[\frac{\Delta}{\Delta+\gamma} R_{s}\right] \ldots
$$

$\mathrm{ET}_{\mathrm{o}}$ is standard evapotranspiration ( $\mathrm{mm} /$ day), $\Delta$ vapor pressure curve $\left(\mathrm{kPa} /{ }^{\circ} \mathrm{C}\right), \gamma$ is psychrometric constant $\left(\mathrm{kPa} /{ }^{\circ} \mathrm{C}\right), R_{s}$ is solar radiation $\left(\mathrm{MJ} / \mathrm{m}^{2} /\right.$ day $), \quad \mathrm{a}$ and $\mathrm{b}$ conversion factor with $a=-0.3 \mathrm{~mm} /$ day and $b$ derived from the equation:

$$
\begin{gathered}
b=1.066-0.13 \times 10^{-2} R H_{\text {mean }}+0.045 U_{d}-0.20 \\
\times 10^{-3} R H_{\text {mean }} U_{d} \\
-0.1315 \times 10^{-4} R H_{\text {mean }}{ }^{2}-0.11 \times 10^{-2} U_{d}{ }^{2} \ldots \ldots(3)
\end{gathered}
$$

$R H_{\text {mean }}$ is daily relative humidity $(\%)$ and $U_{d}$ is average wind velocity at $2 \mathrm{~m}$ height $(\mathrm{m} / \mathrm{s})$

\subsubsection{FAO 24 Blaney-Criddle (24BC)}

(Jensen et al., 1990)

The equation for this model is:

$$
\begin{gathered}
E T_{o}=a+b f \ldots \ldots(4) \\
f=p(0.46 T+8.13) \ldots \ldots(5) \\
a=0.004 R H_{\min }-\frac{n}{N}-1.41 \ldots \ldots(6) \\
b=0.908-0.00483 R H_{\min }+0.7949 \frac{n}{N} \\
+0.768\left[\ln \left(U_{d}+1\right]^{2}\right. \\
-0.0038 R H_{\min } \frac{n}{N}-0.000443 R H_{\min } U_{d} \\
+0.281\left[\ln \left(\frac{n}{N}+1\right)\right] \ldots \ldots(7)
\end{gathered}
$$

$$
-0.0097\left[\operatorname { l n } ( U _ { d } + 1 ] \left[\ln \left(R H_{\min }+1\right]^{2}\left[\ln \left(\frac{n}{N}+1\right)\right]\right.\right.
$$

$\mathrm{ET}_{\mathrm{o}}$ is standard evapotranspiration ( $\mathrm{mm} /$ day), $\mathrm{P}$ is percentage of day length, $\mathrm{T}$ is daily average temperature $\left({ }^{\circ} \mathrm{C}\right), \mathrm{RH}$ is minimum relative humidity $(\%), \mathrm{n} / \mathrm{N}$ is ratio of possible actual day, Ud is wind speed at $2 \mathrm{~m}(\mathrm{~m} / \mathrm{s})$

\subsubsection{FAO 24 Pan Evaporation (24PAN) Doorenbos and} Pruitt (1977)

The equation of this model is

$$
\begin{aligned}
& \quad E T_{o}=K_{p} \times E_{\text {pan }} \ldots \ldots \text { (8) } \\
& K_{p} \\
& =0.108-0.028 u_{2}+0.0422 \ln (F E T) \\
& +0.1434 \ln \left(R H_{\text {mean }}\right) \\
& -0.000631[\ln (F E T)]^{2} \ln \left(R H_{\text {mean }}\right) \ldots \ldots \text { (g) }
\end{aligned}
$$

$\mathrm{ET}_{\mathrm{o}}$ is standard evapotranspiration (mm/day), $K_{p}$ is pan coefficient, $E_{\text {pan }}$ is class A Pan evaporation (mm/day), $u_{2}$ is average wind speed $(\mathrm{m} / \mathrm{s}), R H_{\text {mean }}$ relative humidity (\%), dan FET is distance between pan and green crops (m).

\subsubsection{Linacre (LINA) (Linacre, 1977)}

The equation of this model is:

$$
\begin{gathered}
E T_{o}=\frac{\left(\frac{500 T_{m}}{100-A}\right)+15\left(T-T_{d}\right)}{(80-T)} \ldots \ldots(10) \\
T_{m}=T+0.006 h \ldots \ldots(11)
\end{gathered}
$$

$E T_{o}$ is standard evapotranspiration ( $\mathrm{mm} /$ day) $T$ is mean temperature $\left({ }^{\circ} \mathrm{C}\right), A$ is latitude of the climate station $\left(^{\circ}\right)$, $T_{m}$ is elevation of climate station (m), dan $T_{d}$ is average dew point temperature $\left({ }^{\circ} \mathrm{C}\right) . T_{d}$ equation is:

$$
T_{d}=\left(\frac{f}{100}\right)^{\frac{1}{8}}(112+0.9 T)+0.1 T-112 \ldots \ldots
$$

is average dew point temperature $\left({ }^{\circ} \mathrm{C}\right), \quad T$ is mean temperature $\left({ }^{\circ} \mathrm{C}\right)$, dan $f$ is average daily relative humidity $(\%)$.

2.1.6 Makkink (Makk) (Makkink, 1957).

The equation of this model is:

$$
E T_{o}=0.61 \frac{\Delta}{\Delta+\gamma} \frac{R_{s}}{2.45}-0.12 \ldots \ldots
$$

$\mathrm{ET}_{\mathrm{o}}$ is average dew point temperature $\left({ }^{\circ} \mathrm{C}\right) . \mathrm{R}_{\mathrm{s}}$ is solar radiation $\left(\mathrm{MJ} / \mathrm{m}^{2} /\right.$ day $), \Delta$ is vapor pressure curve $\left(\mathrm{kPa} /{ }^{\circ} \mathrm{C}\right)$, and $\gamma$ is psychrometric constant $\left(\mathrm{kPa} /{ }^{\circ} \mathrm{C}\right)$. 
2.1.7 FAO 56 PM (56PM) (Allen et al., 1998)

The equation of this model is

$$
E T_{o}=\frac{0.408 \Delta\left(R_{n}-G\right)+\gamma \frac{900}{T+273} U_{2}\left(e_{s-} e_{a}\right)}{\Delta+\gamma\left(1+0.34 U_{2}\right)} \ldots \ldots
$$

$\mathrm{ET}_{\mathrm{o}}$ is standard evapotranspiration ( $\mathrm{mm} /$ day), $\mathrm{Rn}$ is netto radiation on crops surface $\left(\mathrm{MJ} / \mathrm{m}^{2} /\right.$ day), $\mathrm{G}$ is continuous heat flux to soil depth $\left(\mathrm{MJ} / \mathrm{m}^{2} /\right.$ day $), \mathrm{T}$ is daily temperature at $2 \mathrm{~m}\left({ }^{\circ} \mathrm{C}\right), \mathrm{u}_{2}$ is wind speed at $2 \mathrm{~m}(\mathrm{~m} / \mathrm{s}), \mathrm{e}_{\mathrm{s}}$ is vapor pressure $(\mathrm{kPa}), \mathrm{e}_{\mathrm{a}}$ is actual vapor pressure $(\mathrm{kPa}), \Delta$ vapor pressure curve $\left(\mathrm{kPa} /{ }^{\circ} \mathrm{C}\right)$, and $\gamma$ is psychrometric constant $\left(\mathrm{kPa} /{ }^{\circ} \mathrm{C}\right)$.

In this study the $\mathrm{ET}_{\mathrm{o}}$ estimation from FAO 56 PenmanMonteith model as the standard model was calculated using CROPWAT. CROPWAT is a ccomputer program recommended by FAO based on FAO 56 PenmanMonteith model (Allen et al., 1998)

\subsubsection{Indicators}

The error indicators equation used to evaluate the model follows Wilmorth (1982):

$$
\begin{gathered}
R M S E=\sqrt{\frac{1}{N} \sum_{i=1}^{N}\left(E T_{o s i}-E T_{o m i}\right)^{2} \ldots \ldots} \\
M A E=\frac{1}{N} \sum_{i=1}^{N}\left|E T_{o s i}-E T_{o m i}\right| \ldots \ldots(16) \\
L O G=\sqrt{\frac{1}{N} \sum_{i=1}^{N}\left(\log E T_{o s i}-\log E T_{o m i}\right)^{2} \ldots \ldots} \\
I . A=1-\frac{\sum\left(E T_{o s i}-E T_{o m i}\right)^{2}}{\sum\left[\left|E T_{o s i}^{\prime}\right|+\left\|E T_{o m i}{ }^{\prime}\right\|\right]^{2}} \ldots \ldots(18) \\
E T_{o s i}^{\prime}=E T_{o s i}-\overline{E T_{o m i} \ldots \ldots(19)} \\
E T_{o m i}^{\prime}=E T_{o m i}-\overline{E T_{o m i}} \ldots \ldots(20)
\end{gathered}
$$

With $E T_{o s i}$ is Penman-Monteith standard evapotranspiration as the standard model -i, dan $E T_{o m i}$ is others evapotranspirasi models (i).

Table.1: Climate parameters needed by each estimation model

\begin{tabular}{|l|l|l|c|c|c|c|c|c|c|}
\hline No & & \multicolumn{10}{|c|}{ Climate data needed by each model } \\
\hline & Model & $\mathrm{E}_{\mathrm{pan}}$ & $\mathrm{T}$ & $\mathrm{R}_{\mathrm{s}}$ & $\mathrm{R}_{\mathrm{n}}$ & $\mathrm{RH}$ & $\mathrm{P}$ & $\mathrm{U}_{2}$ & $\mathrm{R}_{\mathrm{a}}$ \\
\hline $\mathbf{1}$ & $56 \mathrm{PM}$ & & $\sqrt{ }$ & $\sqrt{ }$ & $\sqrt{ }$ & $\sqrt{ }$ & $\sqrt{ }$ & $\sqrt{ }$ & $\sqrt{ }$ \\
\hline $\mathbf{2}$ & H/S & & $\sqrt{ }$ & & & & & & $\sqrt{ }$ \\
\hline $\mathbf{3}$ & $24 \mathrm{RD}$ & & $\sqrt{ }$ & $\sqrt{ }$ & & $\sqrt{ }$ & & $\sqrt{ }$ & \\
\hline $\mathbf{4}$ & $24 \mathrm{BC}$ & & $\sqrt{ }$ & & $\sqrt{ }$ & $\sqrt{ }$ & $\sqrt{ }$ & $\sqrt{ }$ & \\
\hline $\mathbf{5}$ & $24 \mathrm{PAN}$ & $\sqrt{ }$ & & & & $\sqrt{ }$ & & $\sqrt{ }$ & \\
\hline $\mathbf{6}$ & Makk & & $\sqrt{ }$ & $\sqrt{ }$ & & & & & \\
\hline $\mathbf{7}$ & LINA & & $\sqrt{ }$ & & & & & & \\
\hline
\end{tabular}

Notes: $\mathrm{E}_{\mathrm{pan}}$ : Evaporation pan (mm/day); $\mathrm{T}$ : average, maximum and minimum temperature $\left({ }^{\circ} \mathrm{C}\right)$; $\mathrm{R}_{\mathrm{s}}$ : solar radiation( $\mathrm{MJ} / \mathrm{m}^{2} /$ day); $\mathrm{R}_{\mathrm{n}}$ : nett radiation $\left(\mathrm{MJ} / \mathrm{m}^{2} /\right.$ day); $\mathrm{RH}$ : relative humidity (\%); P: day length (\%); $\mathrm{U}_{2}$ : wind velocity $(\mathrm{m} / \mathrm{s}) ; \mathrm{R}_{\mathrm{a}}$ : radiation at the top of the atmosphere $\left(\mathrm{MJ} / \mathrm{m}^{2} /\right.$ day)
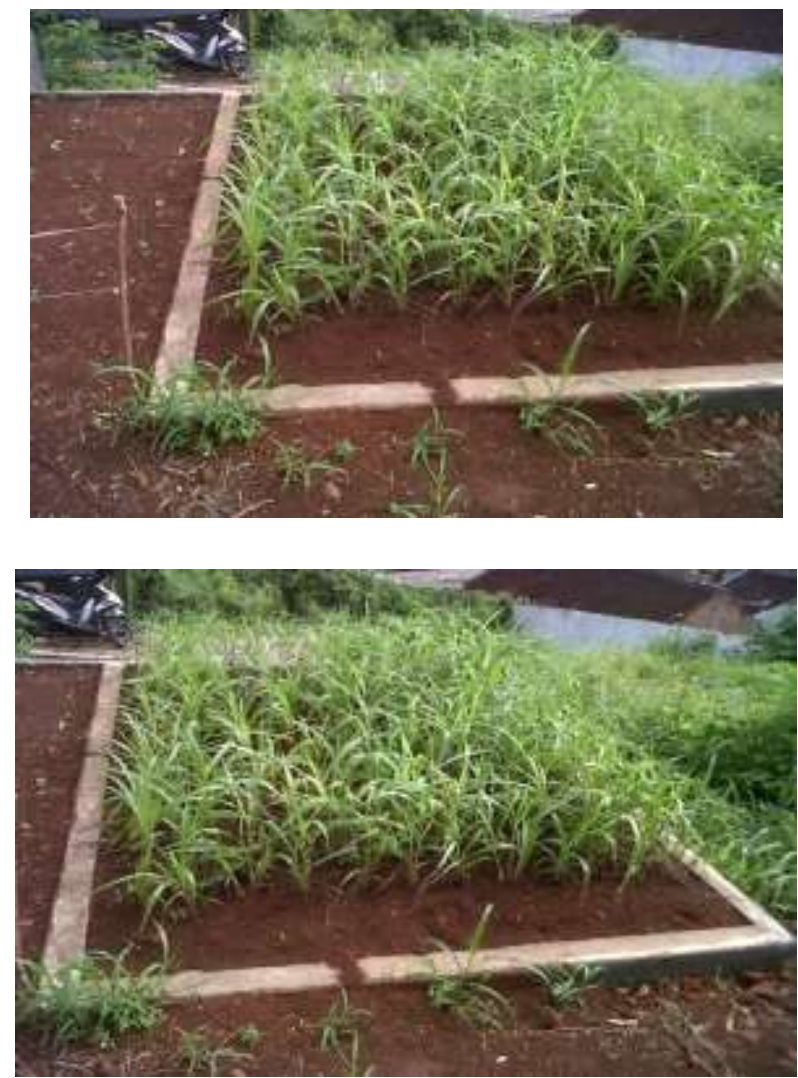

Fig.1: The lysimeters

\section{RESULTS AND DISCUSSIONS}

\subsection{Statistical analysis}

The statistical analysis from daily evapotranspiration data including the error indicator of each model compare to the FAO 56 PM as the standard is presented in Table 2-5.

Table.2: RMSE value among the ET $T_{0}$ estimating models

\begin{tabular}{|l|l|l|l|l|l|l|l|}
\hline \multicolumn{1}{|c|}{ RMSE } \\
\hline & $56 \mathrm{PM}$ & Makk & 24BC & 24PAN & 24RD & H/S & Lina \\
\hline $56 \mathrm{PM}$ & 0 & 0,34 & 1,30 & 0,75 & 0,69 & 1,35 & 0,88 \\
\hline
\end{tabular}




\begin{tabular}{|l|l|l|l|l|l|l|l|}
\hline Makk & 0,34 & 0 & 1,61 & 0,48 & 0,49 & 1,52 & 1,12 \\
\hline 24BC & 1,30 & 1,61 & 0 & 1,99 & 1,92 & 1,12 & 0,79 \\
\hline 24PAN & 0,75 & 0,48 & 1,99 & 0 & 0,33 & 1,93 & 1,54 \\
\hline 24RD & 0,69 & 0,49 & 1,92 & 0,33 & 0 & 1,98 & 1,54 \\
\hline H/S & 1,35 & 1,52 & 1,12 & 1,93 & 1,98 & 0 & 0,59 \\
\hline Lina & 0,88 & 1,12 & 0,79 & 1,54 & 1,54 & 0,59 & 0 \\
\hline
\end{tabular}

Comparison of error indicator (RMSE) between models using monthly data was presented in Table 2. Based on the comparison among the six models, the error indicator RMSE ranged from 0.33-1.99 which means that $\mathrm{ET}_{\mathrm{o}}$ difference among the models was $0.32 \mathrm{~mm}$ to $1.99 \mathrm{~mm} /$ day. This is not a small number since $1 \mathrm{~mm} /$ day ET in 1 ha area is equivalent with water loss of 10,000 liter/day or 3.6 million liter/year.

Using Lampung climate data, the lowest RMSE was found between FAO 24 Radiation and FAO 24 Pan Evaporation while the highest RMSE was found between model FAO 24 Pan Evaporation and FAO 24 Blaney-Criddle.

Tabel.3: MAE value of estimated monthly evapo- transpiration data among the models

\begin{tabular}{|l|l|l|l|l|l|l|l|}
\hline \multicolumn{10}{|c|}{ MAE } \\
\hline & $\begin{array}{l}56 \mathrm{P} \\
\mathrm{M}\end{array}$ & $\begin{array}{l}\text { Mak } \\
\mathrm{k}\end{array}$ & $\begin{array}{l}\text { 24B } \\
\mathrm{C}\end{array}$ & $\begin{array}{l}\text { 24PA } \\
\mathrm{N}\end{array}$ & $\begin{array}{l}\text { 24R } \\
\mathrm{D}\end{array}$ & $\mathrm{H} / \mathrm{S}$ & $\begin{array}{l}\text { Lin } \\
\mathrm{a}\end{array}$ \\
\hline 56PM & 0 & 0,28 & 1,06 & 0,62 & 0,67 & 1,28 & $\begin{array}{l}0,8 \\
6\end{array}$ \\
\hline Makk & 0,28 & 0 & 1,28 & 0,40 & 0,45 & 1,50 & $\begin{array}{l}1,0 \\
8\end{array}$ \\
\hline 24BC & 1,06 & 1,28 & 0 & 1,69 & 1,74 & 0,95 & $\begin{array}{l}0,6 \\
8\end{array}$ \\
\hline $\begin{array}{l}\text { 24PA } \\
\mathrm{N}\end{array}$ & 0,62 & 0,40 & 1,69 & 0 & 0,25 & 1,90 & $\begin{array}{l}8 \\
8\end{array}$ \\
\hline
\end{tabular}

\begin{tabular}{|l|l|l|l|l|l|l|l|}
\hline 24RD & 0,67 & 0,45 & 1,74 & 0,25 & 0 & 1,95 & $\begin{array}{l}1,5 \\
3\end{array}$ \\
\hline H/S & 1,28 & 1,50 & 0,95 & 1,90 & 1,95 & 0 & 7 \\
\hline Lina & 0,86 & 1,08 & 0,68 & 1,48 & 1,53 & 0,47 & 0 \\
\hline
\end{tabular}

The second error indicator (MAE) is presented in Table 3. Similar results with RMSE were found in error indicators for both MAE and log RMSE (Table 4). Makkink model was the model which is closest to FAO 56 Penman Monteith.

Table.4: LOG RMSE among the estimating models of $E T_{0}$

\begin{tabular}{|l|l|l|l|l|l|}
\hline \multicolumn{7}{|c|}{ LOG RMSE } \\
\hline & $56 \mathrm{PM}$ & Makk & 24BC & 24PAN & 24RD \\
\hline 56PM & 0 & 0,04 & 0,13 & 0,11 & 0,10 \\
\hline Makk & 0,04 & 0 & 0,17 & 0,08 & 0,07 \\
\hline 24BC & 0,13 & 0,17 & 0 & 0,23 & 0,22 \\
\hline 24PAN & 0,11 & 0,08 & 0,23 & 0 & 0,06 \\
\hline 24RD & 0,10 & 0,07 & 0,22 & 0,06 & 0 \\
\hline H/S & 0,14 & 0,16 & 0,11 & 0,23 & 0,23 \\
\hline Lina & 0,10 & 0,13 & 0,08 & 0,20 & 0,19 \\
\hline
\end{tabular}

MAE between FAO 56 Penman-Monteith and other models ranges from $0.28 \mathrm{~mm} /$ day (Makkink) up to 1.28 $\mathrm{mm}$ /day (Hargreaves-Samani 1985) and LOG RMSE ranges from $0.04 \mathrm{~mm} /$ day (Makkink) to $0.14 \mathrm{~mm} /$ day (Hargreaves-Samani).

Table 5 showed the results of Index of Agreement (IA). Consistently, Makkink model gave the best results with IA 0.78 followed by Linarch $(0.42)$ and FAO Pan Evaporation (0.42)

Tabel.5: Index of Agreement among the models

\begin{tabular}{|l|l|l|l|l|l|l|l|}
\hline \multicolumn{9}{|c|}{ I.A } \\
\hline & PM & MK & BC & Pan & 24 RD & HS & Ln \\
\hline PM & 1 & 0,78 & 0,09 & 0,42 & 0,55 & 0,26 & 0,42 \\
\hline MK & 0,78 & 1 & $-0,35$ & 0,80 & 0,81 & 0,10 & 0,10 \\
\hline BC & 0,09 & $-0,35$ & 1 & $-0,40$ & $-0,22$ & 0,79 & 0,85 \\
\hline Pan & 0,42 & 0,80 & $-0,40$ & 1 & 0,95 & $-0,03$ & $-0,08$ \\
\hline 24 RD & 0,55 & 0,81 & $-0,22$ & 0,95 & 1 & $-0,03$ & $-0,01$ \\
\hline HS & 0,26 & 0,10 & 0,79 & $-0,03$ & $-0,03$ & 1 & 0,93 \\
\hline Ln & 0,42 & 0,10 & 0,85 & $-0,08$ & $-0,01$ & 0,93 & 1 \\
\hline
\end{tabular}

The resume of statistical analysis from daily evapo transpiration data including the error indicator of each model compare to the FAO $56 \mathrm{PM}$ as the standard was presented in Table 6. 
Table.6: Statistical of daily evapotranspiration data from each model

\begin{tabular}{|l|l|l|l|l|l|l|r|}
\hline \multicolumn{7}{|c|}{ Evapotranspiration Model } \\
\hline \multirow{3}{*}{$\begin{array}{l}\text { Average } \\
\text { STD }\end{array}$} & 24 & BC & HS & Mk & Lin & Pan & FAO \\
\cline { 2 - 8 } RMSE & 2,851 & 4,607 & 4,821 & 3,306 & 4,387 & 2,925 & 3,533 \\
\cline { 2 - 8 } MAE & 0,485 & 1,419 & 0,561 & 0,370 & 0,569 & 1,009 & 0,774 \\
\cline { 2 - 8 } LOG RMSE & 0,884 & 1,392 & 1,481 & 0,683 & 1,065 & 1,283 & \\
\cline { 2 - 8 } I.A & 0,749 & 1,107 & 1,294 & 0,571 & 0,890 & 1,037 & \\
\cline { 2 - 8 } & 0,117 & 0,130 & 0,170 & 0,088 & 0,131 & 0,239 & \\
\cline { 2 - 8 } & 0,439 & 0,565 & $-0,403$ & 0,595 & 0,263 & 0,363 & \\
\hline
\end{tabular}

Table 6 showed that among the models, Makink model consistantly had the smallest RMSE, MAE and Log RMSE compared to PM model and had the highest agreement. On the other hand HS model had the biggest RMSE, MAE and log RMSE with the lowest agreement. Therefore, for Lampung, estimation ET model with the closest estimation to FAO 56 Penman-Monteith was Makkink model. It can be concluded that Makkink model was the suitable simple model that should be chosen in Lampung to calculate $\mathrm{ET}_{\mathrm{o}}$ besides the recommended one, FAO 56 Penman Monteith, especially when the climate data is limited.

So far the estimating model that broadly used is FAO 24 PAN which is based on observation on Pan A evaporation pan. In this study this model did not give a good estimation compared to the FAO 56 PM model (RMSE 0.75; MAE 0.62; Log RMSE 0.11 and IA 0.42). In comparing 24 PAN model to $56 \mathrm{PM}$, using 3 years data in 2 stations in Lampung, Manik et al. (2012) found that the coefficient correlation between those two models are low ( $r=0.3$ for Branti Station and 0.5 for Masgar station).

Daily modeled $\mathrm{ET}_{\mathrm{o}}$ results from each model in 1 year is presented in Figure 2. Most of the models had similar trends with FAO 56 PM but with different estimation. Some models underestimated FAO 56 PM (Makkink, FAO 24 Radiation and FAO 24 Pan Evaporation) while some overestimated ( Blanney Criddle, HargreavesSamani 1985 and Linarch). Makkink model had good estimation to FAO 56 PM in wet months October-March, and slightly underestimated in dry months March October.

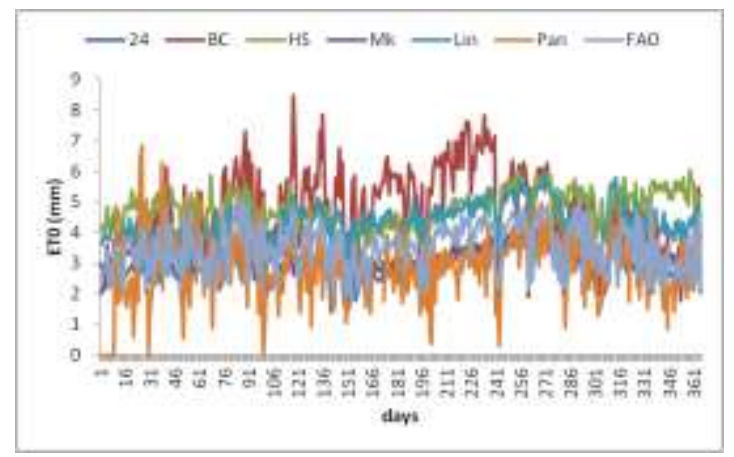

Fig.2: Daily estimation of evapotranspiration from different models
In general, Makkink model is a function of $\mathrm{R}_{\mathrm{s}}$ (solar radiation $\mathrm{MJ} / \mathrm{m}^{2} /$ day), $\Delta$ (slope of vapour pressure), and $\gamma$ (psychrometric constant). Makkink is a simple model since $\gamma$ is $66,1\left(\mathrm{kPa} /{ }^{\circ} \mathrm{C}\right)$, while $\mathrm{R}_{\mathrm{s}}$ and $\Delta$ could be calculated using following equations (Allen, et al., 1998):

$$
\begin{gathered}
R_{S}=K_{R s} \sqrt{\left(T_{\max }-T_{\min }\right)} R_{a} \ldots \ldots \\
\Delta=\frac{4098\left[0,6108 \exp \left(\frac{17,27 T}{T+237,3}\right)\right]}{(T+237,3)^{2}} \ldots \ldots
\end{gathered}
$$

$K_{R s}$ is a coefficient, 0.16 for interior land area and 0.19 for coastal area, $R_{a}$ is top solar radiation $\left(\mathrm{MJ} / \mathrm{m}^{2} /\right.$ day). Basically, this model can be calculated using only maximum and minimum temperature $\left({ }^{\circ} \mathrm{C}\right)$ which is more available in most research stations.

Irmak, Allen and Whitty (2003) conducted a research using daily measured weather data for a 23-year (19782000) in North-Central Florida to examine twenty one $\mathrm{ET}_{0}$ methods (excluding the FAO 56-PM; 10 combination methods, 4 radiation methods, 5 temperature methods and 2 pan evaporation methods) and the results showed that the performance of all radiation methods including Makkink was poorer than that of all combination methods except the Stephens-Stewart method, which performed better than the original PM combination method. Makkink methods had a similar standard error of estimate for all months with the Stephens-Stewart method, but the method significantly underestimated $\mathrm{ET}_{0}$ throughout the year.

The tendency to underestimate high evaporative demand in Makkink model has been found in most of previous studies e.g. in Korea (Chen, et al., 2005), in Germany (Xu and Chen, 2005) in Jordan (Mohawesh, 2011) in Iran (Bakhtiari et al., 2011); those results might be related to the ignorance of the significant influence of wind speed on $\mathrm{ET}_{0}$. Regardless of that, Makkink model was considered as a good option model and the closest to Penman Monteith method in India (Haldar, Kumar and Sehgal, 2005) and in Hungary (Racz, et al., 2013). 
3.2. Comparing Makkink model with direct measurement Direct evapotranspiration measurement was done using lysimeters. Measuring water input and out put together with soil water content on the lysimeters was a challenge. During this research the measurements were repeated several times, however due to technical problems they were not always done in the same day. Therefore, the results (Table 7 and 8 ) were considered as an average number.
In average from Table 7 and 8 , evapotranspiration rate during the research was $3.8+1.11=4.91 \mathrm{~mm} /$ day, higher than estimated Makkink (3.306 mm) and FAO (3.533 $\mathrm{mm}$ ) (Table 6). In general, the average and accumulation of observed Pan A gave slightly higher evapotranspirasion compared to estimated Makkink. However, observed Pan A had much wider standard deviation; Makkink model gave more flat result in daily estimation while Pan A was more fluctuative.

Table.7: Water input and output to the lysimeters

\begin{tabular}{|c|c|c|c|c|}
\hline $\begin{array}{l}\text { Time of Observation } \\
\text { (n) }\end{array}$ & $\begin{array}{l}\text { Rainfal (R) } \\
(\mathrm{mm})\end{array}$ & $\begin{array}{l}\text { Irrigation (I) } \\
(\mathrm{mm})\end{array}$ & $\begin{array}{l}\text { Percolation }(\mathrm{P}) \\
(\mathrm{mm})\end{array}$ & $\begin{array}{l}\mathrm{R}+\mathrm{I}-\mathrm{P} \\
(\mathrm{mm})\end{array}$ \\
\hline 1 & 0.00 & 0.00 & 0.00 & 0.00 \\
\hline 2 & 0.00 & 0.00 & 0.00 & 0.00 \\
\hline 3 & 0.00 & 0.00 & 0.00 & 0.00 \\
\hline 4 & 0.00 & 0.00 & 0.00 & 0.00 \\
\hline 5 & 3.30 & 0.00 & 0.00 & 0.00 \\
\hline 6 & 0.00 & 0.00 & 0.00 & 0.00 \\
\hline 7 & 43.00 & 0.00 & 0.00 & 0.00 \\
\hline 8 & 9.40 & 0.00 & 0.00 & 0.00 \\
\hline 9 & 26.50 & 0.00 & 0.00 & 0.00 \\
\hline 10 & 1.00 & 0.00 & 0.00 & 0.00 \\
\hline 11 & 12.50 & 0.00 & 2.70 & 9.80 \\
\hline 12 & 0.00 & 0.00 & 4.17 & -4.17 \\
\hline 13 & 0.00 & 0.00 & 1.62 & -1.62 \\
\hline 14 & 0.00 & 0.00 & 0.76 & -0.76 \\
\hline 15 & 0.00 & 10.00 & 0.38 & 9.62 \\
\hline 16 & 0.00 & 15.00 & 0.24 & 14.76 \\
\hline 17 & 2.00 & 0.00 & 1.21 & 0.79 \\
\hline 18 & 9.00 & 0.00 & 1.19 & 7.82 \\
\hline 19 & 0.00 & 0.00 & 2.07 & -2.07 \\
\hline 20 & 0.00 & 0.00 & 0.66 & -0.66 \\
\hline 21 & 0.00 & 0.00 & 0.26 & -0.26 \\
\hline 22 & 5.00 & 0.00 & 0.00 & 0.00 \\
\hline 23 & 2.70 & 0.00 & 0.18 & 2.52 \\
\hline 24 & 5.00 & 0.00 & 0.03 & 4.97 \\
\hline 25 & 0.50 & 0.00 & 0.02 & 0.48 \\
\hline 26 & 0.00 & 15.00 & 0.00 & 15.00 \\
\hline 27 & 0.00 & 0.00 & 0.00 & 0.00 \\
\hline 28 & 0.00 & 10.00 & 0.00 & 10.00 \\
\hline 29 & 3.00 & 0.00 & 2.30 & 0.70 \\
\hline 30 & 3.50 & 0.00 & 1.75 & 1.75 \\
\hline 31 & 0.00 & 0.00 & 0.00 & 0.00 \\
\hline 32 & 5.50 & 0.00 & 0.00 & 5.50 \\
\hline 33 & 0.00 & 0.00 & 0.23 & -0.23 \\
\hline
\end{tabular}




\begin{tabular}{|c|c|c|c|c|}
\hline $\begin{array}{c}\text { Time of Observation } \\
(\mathrm{n})\end{array}$ & $\begin{array}{c}\text { Rainfal }(\mathrm{R}) \\
(\mathrm{mm})\end{array}$ & $\begin{array}{c}\text { Irrigation }(\mathrm{I}) \\
(\mathrm{mm})\end{array}$ & $\begin{array}{c}\text { Percolation(P) } \\
(\mathrm{mm})\end{array}$ & $\begin{array}{c}\mathrm{R}+\mathrm{I}-\mathrm{P} \\
(\mathrm{mm})\end{array}$ \\
\hline 34 & 3.40 & 0.00 & 0.00 & 3.40 \\
35 & 0.50 & 0.00 & 0.17 & 0.33 \\
36 & 3.20 & 0.00 & 0.02 & 3.18 \\
37 & 0.00 & 11.67 & 0.02 & 11.65 \\
38 & 0.00 & 53.33 & 0.00 & 53.33 \\
39 & 0.00 & 0.00 & 3.00 & -3.00 \\
40 & 2.60 & 0.00 & 1.53 & 1.08 \\
41 & 0.50 & 0.00 & 0.73 & -0.23 \\
42 & 3.20 & 0.00 & 0.00 & 0.00 \\
43 & 0.00 & 0.00 & 0.44 & -0.44 \\
44 & 0.00 & 0.00 & 0.00 & 0.00 \\
45 & 0.00 & 0.00 & 0.08 & -0.08 \\
46 & 0.00 & 0.00 & 0.11 & -0.11 \\
47 & 24.00 & 0.00 & 0.00 & 24.00 \\
48 & 0.00 & 0.00 & 0.71 & -0.71 \\
49 & 0.00 & 0.00 & 0.00 & 0.00 \\
50 & 0.60 & 0.00 & 0.00 & 0.60 \\
51 & 0.00 & 0.00 & 0.00 & 0.00 \\
52 & 0.00 & 0.00 & 0.00 & 0.00 \\
53 & 1.00 & 0.00 & 0.00 & 1.00 \\
54 & 0.00 & 0.00 & 0.00 & 0.00 \\
55 & 29.50 & 0.00 & 0.00 & 29.50 \\
56 & 44.90 & 0.00 & 0.00 & 44.9 \\
57 & 0.00 & 0.00 & 0.00 & 0.00 \\
58 & 0.00 & 0.00 & 0.00 & 0.00 \\
59 & 0.00 & 0.00 & 22.00 \\
61 & 0.00 & 0.00 & 0.00 & 8.00 \\
& & 0.00 & 0.00 & 0.40 \\
\hline & & & Average & 3.80 \\
\hline
\end{tabular}

Table.8: Soil water content of the lysimeters

\begin{tabular}{|c|c|c|c|c|c|c|c|c|c|}
\hline $\begin{array}{c}\text { Number of } \\
\text { Observatio } \\
n\end{array}$ & $\begin{array}{c}\text { Soil } \\
\text { Tension }\end{array}$ & $\begin{array}{l}\text { Volumetri } \\
\text { c } \\
\text { Soil water }\end{array}$ & $\begin{array}{l}\text { Daily } \\
\qquad \mathrm{S}\end{array}$ & $\begin{array}{c}\text { Cumulativ } \\
\text { e } \\
\Delta \mathrm{S}\end{array}$ & $\begin{array}{c}\text { Number of } \\
\text { Observatio } \\
n\end{array}$ & $\begin{array}{c}\text { Soil } \\
\text { Tension }\end{array}$ & $\begin{array}{l}\text { Volumetri } \\
\text { c } \\
\text { Soil water }\end{array}$ & $\begin{array}{l}\text { Daily } \\
\Delta \mathrm{S}\end{array}$ & $\begin{array}{c}\text { Cumulativ } \\
\mathrm{e} \\
\Delta \mathrm{S}\end{array}$ \\
\hline (n) & $(\mathrm{k} \Omega)$ & $\begin{array}{l}\text { content } \\
(\%)\end{array}$ & $(\mathrm{mm})$ & $(\mathrm{mm})$ & (n) & $(\mathrm{k} \Omega)$ & $\begin{array}{l}\text { content } \\
(\%)\end{array}$ & $(\mathrm{mm})$ & $(\mathrm{mm})$ \\
\hline 1 & 122 & 43.96 & & & 13 & 171 & 39.20 & -0.41 & -11.90 \\
\hline 2 & 113 & 45.04 & 2.70 & 2.70 & 14 & 168.33 & 39.42 & 0.55 & -11.35 \\
\hline 3 & 131 & 42.96 & -5.21 & -2.51 & 15 & 179 & 38.56 & -2.17 & -13.51 \\
\hline 4 & 143.33 & 41.69 & -3.17 & -5.68 & 16 & 176.67 & 38.74 & 0.46 & -13.05 \\
\hline 5 & 146.67 & 41.37 & -0.81 & -6.49 & 17 & 188.33 & 37.84 & -2.25 & -15.30 \\
\hline 6 & 157.33 & 40.38 & -2.47 & -8.96 & 18 & 203.33 & 36.76 & -2.70 & -18.01 \\
\hline 7 & 160 & 40.14 & -0.59 & -9.56 & 19 & 236.67 & 34.62 & -5.35 & -23.36 \\
\hline 8 & 154 & 40.68 & 1.35 & -8.21 & 20 & 280 & 32.25 & -5.93 & -29.28 \\
\hline 9 & 153.67 & 40.71 & 0.08 & -8.14 & 21 & 246.67 & 34.04 & 4.47 & -24.82 \\
\hline 10 & 152.67 & 40.80 & 0.23 & -7.91 & 22 & 249 & 33.90 & -0.33 & -25.15 \\
\hline 11 & 148.33 & 41.21 & 1.02 & -6.89 & 23 & 251.67 & 33.75 & -0.38 & -25.52 \\
\hline 12 & 169 & 39.37 & -4.60 & -11.49 & & & & average & -1.11 \\
\hline
\end{tabular}


Table.8: Estimation of ET $T_{0}$ comparing Pan A with The Makink

\begin{tabular}{|l|c|c|c|c|c|c|}
\hline \multirow{4}{*}{ Average Sum Standard } & \multicolumn{2}{|c|}{ April } & \multicolumn{2}{c|}{ May } & \multicolumn{2}{c|}{ June } \\
\cline { 2 - 7 } Deviation & Pan A & Makink & Pan A & Makink & Pan A & Makink \\
\cline { 2 - 7 } & & & & & & \\
& 3.96 & 3.39 & 3.40 & 3.45 & 4.19 & 3.40 \\
& 118.72 & 101.80 & 105.50 & 106.99 & 121.38 & 98.66 \\
& 2.15 & 0.25 & 1.61 & 0.36 & 2.01 & 0.30 \\
\hline
\end{tabular}

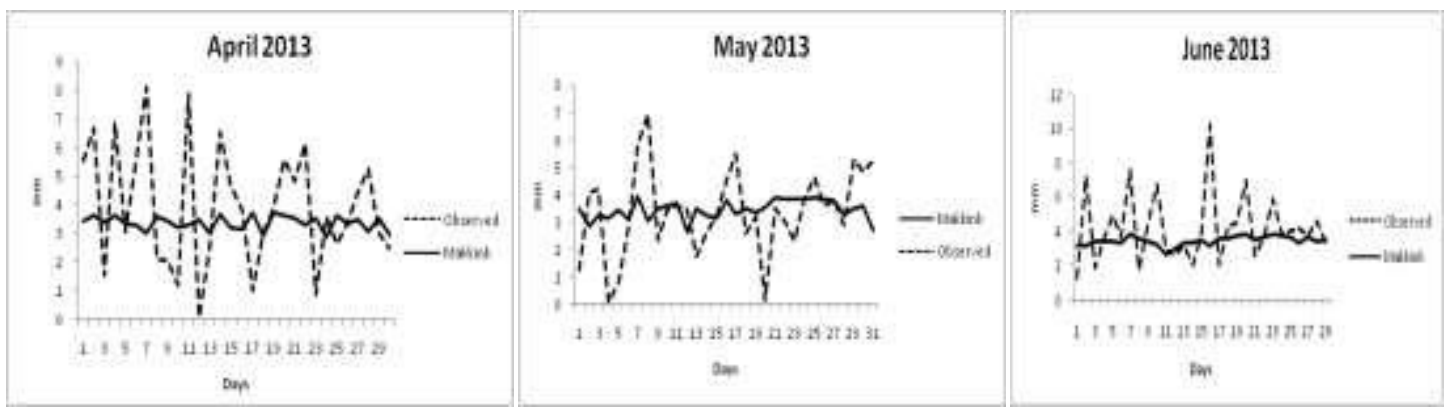

Fig.3: Daily evapotranspiration from observed Pan A compared to estimated Makkink.

\section{CONCLUSION}

This study concluded that Makkink model is a simple model that can be chosen in Lampung as an alternative to estimate standard evapotranspiration in an area with limited climate data needed to apply FAO 56 PM, with a note that Makkink tended to be underestimated during dry months. Estimation of evapotranspiration using models are sufficient for averaged and accumulated result from some period of time, not for daily or single measuremnt.

\section{REFERENCES}

[1] Allen, R. G., Pereira, L. S., Raes, D., and Smith, M. 1998. "Crop Evapotranspiration: Guidelines For Computing Crop Requirements." Irrigation and Drainage Paper No. 56, FAO, Rome, Italy.

[2] Bakhtiari, B, N. Ghahreman, A. M. Liaghat and G. Hoogenboom. 2011. Evaluation of Reference Evapotranspiration Models for aSemiarid Environment Using Lysimeter Measurements. J. Agr. Sci. Tech. 13: 223-237.

[3] Berengena, J dan P. Gavilan, 2005.Reference Evapotranspiration Estimation in a Highly Advective Semiarid Environment.Journal of Irrigation and darinage Engineering. 131(2): 147 163

[4] Chen, J.F., H.F. Yeh, C.H. Lee and W.C. Lee and W.C. Lo. 2005. Optimal Comparison of Empirical Equations for Estimating Potential Evapotranspiration in Taiwan. XXXI IAHR Congress. 3867-3697 p
[5] Chowdhury, S., M.K. Nanda, S. Madan and G. Saha. 2010. Studies on Yield Limiting Meteorological factors for Production of Rabi Pigeon Pea in West Bengal. Journal of Agrometeorology 12 (1):64-68

[6] Doorebos, J., and Pruitt, W. O. (1977). "Guidelines for predicting crop water requirements." Irrig.and Drain. Paper 24, Food and Agriculture Organization of the United Nations (FAO), Rome, Italy.

[7] Fontenot, R. L. 2004 . "An evaluation of reference evapotranspiration models in Louisiana." MSc thesis, Louisiana State Univ., BatonRouge, La. USA.

[8] Haldar Dipanwita, Gopal Kumar And V.K. Sehgal. 2005. Performance of Different Methods for Computation of ReferenceEvapotranspiration under Semiarid Condition. Jour. Agric. Physics, 5 (1): 5764.

[9] Hargreaves, G.H, and Z.A. Samani. 1985. Reference crop evapotranspiration from temperature. Applied Engineering in Agriculture. 1(2):96-99.

[10] Irmak, S., R. G. Allenand E. B. Whitty.2003. Daily grass and alfalfa-reference evapotranspiration estimates and Alfalfa to grass evapotranspiration ratios in Florida. Journal of Irrigation and Drainage Engineering 129:5(2):360-370.

[11] Itenfisu Daniel, Ronald L. Elliott, Richard G. Allen dan Ivan A. Walter. 2003. Comparison of Reference Evapotranspiration Calculationsas Part of the ASCE Standardization Effort. Journal Of Irrigation and Drainage Engineering 129 (6): 440-448. 
[12] Jacobs, J.M., M.C. Anderson, L.C. Friess and G.R. Diak. 2004. Solar Radiation Long Wave Radiation and Emergent Wetland Evapotranspiration Estimates from Satellite Data in Florida. Hydrological Sciences 49(3): 461-476

[13] Jensen, M.E., R.D. Burman, and R.G. Allen.1990. Evapotranspiration and irrigation water requirements. ASCE manuals and reports onengineering practices No. 70. ASCE. New York.

[14] Linacre, E.T. 1977. A simple formula for estimating evaporation rates in various climates, using temperature data alone. Agricultural Meteorology. 18(6):409-424.

[15] Makkink, G.F. 1957. Testing the Penman formula by means of lysimeters. Journal of the Institution of Water Engineering. 11(3):277-288.

[16] Manik, T.K., R.A.B. Rosadi and A. Karyanto. 2012. Evaluasi Metode Penman Monteith Dalam Menduga Laju Evapotranspirasi Standar di Dataran Rendah Propinsi Lampung Indonesia. Jurnal Keteknikan Pertanian 26(2): 121-128.

[17] Mohawesh, O.E. 2011.Evaluation of evapotranspiration models for estimating daily reference evapotranspiration in arid and semiarid environments. Plant Soil Environ.,57(4): 145-152

[18] Monteith, J. L.1965."Evaporation and Environment."1 $19^{\text {th }}$ Symposium of the Society for Experimental Biology: 205-234.CambridgeUniv. Press,Cambridge.

[19] Penman, H. L.1948. Natural Evaporation From Open Water, Bare SoilAnd Grass.Proc. R. Soc. London, Ser. A,193: 120-146.

[20] Priestley, C.H.B. dan Taylor R.J. 1972. On The Assessment of Surface Heat Flux And Evaporation Using Large-Scale Parameters.Mon Wea Rev 100: 81-92

[21]Rácz Csaba, János Nagy and Attila Csaba Dobos. 2013. Comparison of Several Methods for Calculation of Reference Evapotranspiration. Acta Silv. Lign. Hung 9: 9-24

[22] Schneider, K., B. Ketzer, L. Breuer, K.B. Vach'e, C. Bernhofer and H.G. Frede. 2007. Evaluation of Evapotranspiration Methods for Model Evaluation in a Semi-arid Watershed in Northern China. Adv. Geosci (11): 37-42.

[23] Shuttleworth, W.J., J.S. Wallace. 2009. Calculation The Water Requirement of Irrigated Crops in Australia Using The Matt-Shuttleworth Approach. American Society of Agricultural and Biological Engineers 52(6): 1895- 1906.

[24] Steduto, P., M. Todorovic, A. Caliandro, dan P. Rubino. 2003. Daily Reference Evapotranspiration
Estimates By The Penman-Monteith Equation In Southern Italy.

[25] Constant Vs. Variable Canopy Resistance. Theor. Appl. Climatol. 74: 217-225

[26] Temesgen, Bekele, Simon Eching, Baryohay Davidoff dan Kent Frame. 2005. Comparison of Some Reference Evapotranspiration Equations for California.Journal ofIrrigation and Drainage Engineering 131 (1):73-84

[27] Usman. 2004. Analisis Kepekaan Beberapa Metode Pendugaan Evapotranspirasi Potensial TerhadapPerubahan Iklim. Jurnal Natur Indonesia 6(2): 91-98.

[28] Wang, S, B. J. Fu, G. Y. Gao, X. L. Yao, and J. Zhou. 2012. Soil moisture and evapotranspiration of different land cover types in the Loess Plateau, China. Hydrol. Earth Syst. Sci.16: 2883-2892

[29] Wilmort, Cort.J. 1982. Some Comments On The Evaluation Of Model Performance. Bulletin of American Meteorological Society, 63 (11): 13091313

[30] Xing Zisheng, Lien Chow, Fan-rui Meng, Herb W. Rees, John Monteith, and Stevens Lionel. 2008. Testing Reference Evapotranspiration Estimation MethodsUsing Evaporation Pan and Modeling in Maritime Region of Canada. Journal of Irrigation and Drainage Engineering, 134 (4): 417-424

[31] Xu, C.Y., and D. Chen. 2005. Comparison of seven models for estimation of evapotranspiration and groundwater recharge using lysimeter measurement data in Germany. Hydrological Process.(19):37173734. 